\title{
WSES guidelines updates
}

\author{
Marco Ceresoli ${ }^{1 *}$ D, Federico Coccolini ${ }^{2}$, Walter L. Biffl ${ }^{3}$, Massimo Sartelli ${ }^{4}$, Luca Ansaloni ${ }^{5}$, Ernest E. Moore ${ }^{6}$, \\ Salomone Di Saverio ${ }^{7}$, Yoram Kluger ${ }^{8}$ and Fausto Catena ${ }^{9}$
}

\begin{abstract}
The World Society of Emergency Surgery promotes training and continuing medical education in the field of emergency surgery and trauma. One of the most important activities of the society is the development of guidelines. The debate about the process of developing and updating guidelines is very active with no clear consensus and different policies among scientific societies. The present commentary provides the position of the World Society of Emergency Surgery on guideline development process and their update.
\end{abstract}

Keywords: Guidelines, Evidence-based medicine, Guideline development, Guideline update, WSES

\section{Background}

The World Society of Emergency Surgery (WSES) was established in 2007 with the aim to promote training and continuing medical education in emergency general surgery and trauma.

Since then, great effort was made in that direction: six world congresses with vast international attendance took place and several international educational meetings were initiated as well as numerous educational courses in different fields of trauma and emergency surgery were conducted and above all, WSES launched and curated several clinical guidelines for emergency and trauma surgery $[1,2]$.

Some guidelines have already been updated, and others will be updated in the near future.

\section{Main text}

The debate about the clinical guideline updating process is very animated with many scientific societies facing this problem. No consensus on update timing is acceptable by all $[3,4]$.

No clear agreement exists about the timing and methodology for guideline updates. Some authors advocate

\footnotetext{
* Correspondence: marco.ceresoli@libero.it

${ }^{1}$ General and Emergency Surgery Department, School of Medicine and Surgery, Milano-Bicocca University, Monza, Italy

Full list of author information is available at the end of the article
}

updates every $2-5$ years, and some advocate an update only when relevant evidences are available or recommendations become outdated [5-7].

\section{Generally strong recommendations last longer Are our recommendations really strong?}

The relationship between emergency surgery and evidence-based medicine unfortunately at the moment is a troubled story. Good-quality evidence is frequently lacking in emergency surgery, and the difficulty to conduct randomized trials in emergency settings is well documented [8-10].

In this context, the quality of existing evidences is poor and based mainly on retrospective and observational studies; therefore, the strength of recommendations is often weak, based more on the plausibility that even a well-designed study will not change the clinical practice rather than on the results of randomized trials.

Moreover, the development of clinical guidelines is an extremely complex process that involves laborious work and involvement of an international panel of experts and needs months of work of reviewing the literature, mediating several points of view, and experts' opinions. In the absence of solid and strong evidences, like in emergency surgery, this process becomes harder.

At the light of these considerations, and in order to avoid a waste of time in producing duplicate guidelines 
with similar recommendations, the WSES board has decided to adopt a new policy and recommendations.

- WSES requires a good-quality standard for guidelines; the development of guidelines should be performed according to the AGREE II requirements adopting the GRADE methodology for evidence evaluation and grading $[11,12]$.

- For each guideline topic, WSES will appoint a committee with a coordinator that will be nominated by WSES board who will be in charge of the continuous monitoring of new evidences available about the topic

- The nominated committee will be responsible to add, on a dedicated area in the WSES website, all the relevant updates and new studies. The committee will have to notify and propose to the WSES board the need for guideline updating.

WSES will continue to promote a scientific approach to emergency and trauma surgery and to support the advance of clinical studies such the International Register of Open Abdomen (IROA), the International Register of Emergency Surgery (WIRES), and the ongoing COOL study $[13,14]$ in order to obtain good-quality evidence and the development of a better quality evidence-based approach in the daily practice.

\section{Conclusion}

WSES guidelines will be developed according to highquality standards; a dedicated committee, nominated by the WSES board, will be responsible for the continuous evaluation of new evidences. The development of an updated version of guidelines will be promoted and evaluated by the WSES board in case of important changes and new evidences available.

\section{Abbreviations}

IROA: International Register of Open Abdomen; WIRES: WSES International Register of Emergency Surgery; WSES: World Society of Emergency Surgery

\section{Acknowledgements}

None

\section{Authors' contributions}

All the authors developed and approved the manuscript in its final form.

\section{Funding}

Not applicable

\section{Availability of data and materials}

Not applicable

Ethics approval and consent to participate

Not applicable

\section{Consent for publication}

Not applicable

\section{Competing interests}

All the authors declare to have no competing interests.

\section{Author details}

${ }^{1}$ General and Emergency Surgery Department, School of Medicine and Surgery, Milano-Bicocca University, Monza, Italy. ${ }^{2}$ General, Emergency and Trauma Surgery Department, Pisa University Hospital, Pisa, Italy. ${ }^{3}$ Trauma Surgery Department, Scripps Memorial Hospital La Jolla, San Diego, CA, USA. ${ }^{4}$ General and Emergency Surgery, Macerata Hospital, Macerata, Italy. ${ }^{5}$ General, Emergency and Trauma Surgery Department, Bufalini Hospital, Cesena, Italy.

${ }^{6}$ Trauma Surgery, Denver Health, Denver, CO, USA. ${ }^{7}$ Department of General Surgery, University Hospital of Varese, University of Insubria, Varese, Italy. ${ }^{8}$ Division of General Surgery, Rambam Health Care Center, Haifa, Israel.

${ }^{9}$ Emergency and Trauma Surgery, Maggiore Hospital, Parma, Italy.

Received: 14 April 2020 Accepted: 31 May 2020

Published online: 10 June 2020

\section{References}

1. Catena F, Moore F, Ansaloni L, Leppäniemi A, Sartelli M, Peitzmann AB, et al. Emergency surgeon: "last of the mohicans" 2014-2016 editorial policy WSESWJES: position papers, guidelines, courses, books and original research; from WJES impact factor to WSES congress impact factor. World J Emerg Surg [Internet]. BioMed Central; 2014 [cited 2020 Jan 26];9:14. Available from: http://www.ncbi.nlm.nih.gov/pubmed/24484743.

2. Coccolini F, Kluger Y, Ansaloni L, Moore EE, Coimbra R, Fraga GP, et al. WSES worldwide emergency general surgery formation and evaluation project. World J Emerg Surg [Internet]. BioMed Central; 2018 [cited 2020 Jan 26];13: 13. Available from: https://wjes.biomedcentral.com/articles/10.1186/s13017018-0174-5.

3. Shekelle P, Eccles MP, Grimshaw JM, Woolf SH, Los G, Veterans A, et al. When should clinical guidelines be updated? Education and debate. BMJ [Internet]. 2001;323:155-62 Available from: www.guidelines.gov.

4. Shekelle PG. Updating practice guidelines. JAMA. 2014;311:2072-3.

5. Shekelle PG, Ortiz E, Rhodes S, Morton SC, Eccles MP, Grimshaw JM, et al. Validity of the agency for healthcare research and quality clinical practice guidelines: how quickly do guidelines become outdated? J Am Med Assoc. 2001;286:1461-7.

6. Clark E, Donovan EF, Schoettker P. From outdated to updated, keeping clinical guidelines valid. Int J Qual Heal Care. 2006;18:165-6.

7. Gartlehner G, West SL, Lohr KN, Kahwati L, Johnson JG, Harris RP, et al. Assessing the need to update prevention guidelines: a comparison of two methods. Int J Qual Heal Care. 2004;16:399-406.

8. McCulloch P, Taylor I, Sasako M, Lovett B, Griffin D. Randomised trials in surgery: problems and possible solutions. BMJ [Internet]. BMJ; 2002 [cited 2020 Jan 25];324:1448-51. Available from: http://www.ncbi.n/m.nih.gov/ pubmed/12065273.

9. Morley RL, Edmondson MJ, Rowlands C, Blazeby JM, Hinchliffe RJ. Registration and publication of emergency and elective randomised controlled trials in surgery: a cohort study from trial registries. BMJ Open [Internet]. British Medical Journal Publishing Group; 2018 [cited 2020 Jan 25];8:e021700. Available from: http://www.ncbi.nlm.nih.gov/pubmed/2 9982216.

10. Doig CJ, Page SA, McKee JL, Moore EE, Abu-Zidan FM, Carroll R, et al. Ethical considerations in conducting surgical research in severe complicated intraabdominal sepsis. World J Emerg Surg [Internet]. BioMed Central; 2019 [cited 2020 Jan 25];14:39. Available from: https://doi.org/10.1186/s13017019-0259-9.

11. Guyatt GH, Oxman AD, Vist GE, Kunz R, Falck-Ytter Y, Alonso-Coello P, et al. GRADE: an emerging consensus on rating quality of evidence and strength of recommendations. BMJ [Internet]. 2008 [cited 2019 Jun 1];336:924-6. Available from: http://www.ncbi.nlm.nih.gov/pubmed/18436948.

12. Brouwers MC, Kho ME, Browman GP, Burgers JS, Cluzeau F, Feder G, et al. AGREE II: advancing guideline development, reporting and evaluation in health care. Can Med Assoc J [Internet]. 2010;182:E839-42. Available from: http://www.cmaj.ca/cgi/doi/10.1503/cmaj.090449.

13. Coccolini F, Catena F, Montori G, Ceresoli M, Manfredi R, Nita GE, et al. IROA the International Register of Open Abdomen. World J Emerg Surg [Internet]. World Journal of Emergency Surgery; 2015;10:37. Available from: http:// www.wjes.org/content/10/1/37. 
14. Kirkpatrick AW, Coccolini F, Ansaloni L, Roberts DJ, Tolonen M, McKee $J \mathrm{~L}$, et al. Closed Or Open after Source Control Laparotomy for Severe Complicated Intra-Abdominal Sepsis (the COOL trial): study protocol for a randomized controlled trial. World J Emerg Surg [Internet]. 2018 [cited 2019 Oct 28];13:26. Available from: http://www.ncbi.nlm.nih.gov/ pubmed/29977328.

\section{Publisher's Note}

Springer Nature remains neutral with regard to jurisdictional claims in published maps and institutional affiliations.

Ready to submit your research? Choose BMC and benefit from:

- fast, convenient online submission

- thorough peer review by experienced researchers in your field

- rapid publication on acceptance

- support for research data, including large and complex data types

- gold Open Access which fosters wider collaboration and increased citations

- maximum visibility for your research: over $100 \mathrm{M}$ website views per year

At BMC, research is always in progress.

Learn more biomedcentral.com/submissions 